\title{
Comparative efficacy of garlic, BAU-biofungicide, Bavistin and Tilt on seed borne fungal flora in chilli
}

\author{
M. T. Hossen, M. A. S. Sohag and M. S. Monjil* \\ Department of Plant Pathology, Bangladesh Agricultural University, Mymensingh-2202, Bangladesh \\ *E-mail:smonjil@yahoo.com
}

\begin{abstract}
Efficacy of BAU-Biofungicide (3\%), garlic extract (1:1), Bavistin (0.2\%) and Tilt 250EC (0.2\%) were evaluated against seed borne fungal pathogens of chilli collected from Lakshmonkhola, Mugarchar and Tulatuli villages under Comilla district. Four hundred seeds of each sample were tested following blotter incubation and sand culture method. Using blotter incubation method, five different seed borne fungi, namely, Colletotrichum capsici, Alternaria tenuis, Aspergillus spp, Fusarium spp, and Curvularia lunata were detected from the chilli seeds. BAU-Biofungicide (3\%) and followed by garlic extracts (1:1) was found most effective among five different treatments for increasing the germination percentage as well as controlling the associated seed borne fungi in chilli seed. Highest germination percentage (89.50\%) was observed in BAU-Biofungicide (3\%) treated seeds. Highest reduction of Colletotrichum capsici, Alternaria tenuis, Aspergillus spp, Fusarium spp, and Curvularia lunata was observed when seeds were treated with BAU-Biofungicide (3\%) and garlic extract (1:1). The highest vigour index of chilli seed collected from Lakshmomkhola, Mugarchar and Tulatuli villages were 494.56, 403.23 and 333.37, respectively was observed in BAU-Biofungicide treated seeds.
\end{abstract}

Keywords: Chilli, Seed borne fungi, BAU-biofungicide, Garlic extracts, Seed health

\section{Introduction}

Chilli (capsicum aannuum L.) is one of the important spice crops in the world. In Bangladesh it occupies the second position next to onion. Chilli is the most essential spice in Bangladesh and is used extensively by the all people in their daily food. Dried Chilli is used in Bangladesh as important spice for its pungency and pleasant flavours. It is cultivated in 74,255 ha of area in rabi and in 17,913 ha of area in kharif season with production of $88,772 \mathrm{t}$ and $21,274 \mathrm{t}$, respectively (BBS, 2016). The area and production have been raised but in compare to leading chilli producing countries per unit yield is very low. There are many factors responsible for the low yield of this crop in the country. Out of these, seed borne fungal diseases play a vital role.

In Bangladesh chilli crop in the field suffers from as many as 15 diseases, of which 12 are caused by fungi (Ahmed and Hossain, 1985). Limited work has been done on the control of fungal transmitted pathogens through the seeds of the chilli crop. Proper disease control measures can substantially improve the quality of chilli fruit and significantly increase the yield. Among the disease control practices used, seed treatment is probably the cheapest and safest method of direct plant disease control. In many countries regular practices of seed treatment is considered as an insurance against the building of inocula and has greatly increased the yield and improve the quality in many crops including chilli.

Control of seed borne pathogens of chilli by fungicidal seed treatment is a common method but the use of fungicides are not good for health as well as costly. To get higher yields, the poor and ignorant farmers were using very high doses of toxic and expensive chemicals including different fungicides to control pests and pathogens. Moreover, sowing of seeds treated with fungicides in general results in accumulation of harmful fungicides residues in soil as well as in the plant products causing serious health problems. Indiscriminate use of chemicals break down the natural ecological balance, reduce soil fertility and health of the farmers themselves by wrecking their immune system. It is therefore, judicious to explore less expensive, less risky non chemical methods of pathogen control such as seed treatment. 
Now a day's research all over the world is much interested to control disease by alternate means such as use of bio-agents or plant extracts or elicitors (Monjil et al., 2014; Islam and Monjil, 2016a). Plant extracts increase seed germination and improves seedling vigour (Hasan et al., 2005). Several studies have demonstrated increased seed germination and vigour index in different crops after application of plant extracts (Chowdhury et al., 2005). In addition, bio-control agents have the potential to protect plants against several diverse plant pathogenic fungi. Trichoderma based preparation BAU-Biofungicides has been found to be effective in controlling seed borne disease of crops (Shoulkamy et al., 2006; Hasan and Alam, 2007).

In view of the above information, it is clear that seed borne pathogens of chilli cause vital role in chilli cultivation for reducing considerable yields in the country. Control of seed borne diseases by plant extracts and bio-agents instead of chemicals to avoid environmental pollution is still in the early stage in the country. Considering the above facts the present research work was undertaken to evaluate the efficacy of garlic extracts, BAU-Biofungicide, Bavistin and Tilt for the management of the seed borne pathogens associated in chilli seeds.

\section{Materials and Methods}

The experiment was conducted at the Seed Pathology Center (SPC), and Microbilogy and Biocontrol laboratory, Bangladesh Agricultural University (BAU), Mymensingh during the period from January, 2014 to May, 2015. Seed samples of chilli (Capsicum annuum L) were collected from farmers of three different villages of Meghna Upazila under Comilla districts namely Lakshmomkhola (Sample 1), Mugarchar (Sample 2) and Tulatuli (Sample 3). One hundred grams of seeds for each sample were collected for health study.

\section{Seed treatments with Garlic extract, BAU-biofungicide and chemical fungicides}

Five treatments viz., $T_{1}=$ Control; $T_{2}=$ Garlic @ (1:1) w/v; $T_{3}=$ BAU biofungicide @ 0.3\%, $T_{4}=$ Bavistin (Carbendazin) @ $0.2 \%$ and $\mathrm{T}_{5}=$ Tilt (Propiconazol) @ 0.2\% were used. Garlic extract and chemical fungicides were prepared following method described by Islam and Monjil (2016). Chilli seeds were treated following dipping method. The seeds were dipped into garlic extract (1:1) for 20 minutes. The treated seeds were blotted dry in open air for one hour. A set of control was maintained by dipping the seeds in tap water. Three replications were used for each treatment. After incubating the treated seeds, and germination of seeds was counted and fungi yielded on seeds were observed.

BAU-Biofungicide was received from Eco-friendly Plant Disease Management Laboratory, Department of Plant Pathology, Bangladesh Agricultural University, Bangladesh. Moistened chilli seeds were taken in a beaker and BAU-Biofungicide added to it. The seeds were shaken vigorously for mixing BAU-Biofungicide on the seed surface. BAU-Biofungicide @ 3\% of seed weight was used to treat the chilli seeds.

\section{Seed Health Testing}

Seed health was examined following standard Blotter Method in accordance to the International rules of Seed Testing Association (ISTA, 2001). Seeds produced both plumule and radical after incubation were considered as sprouted seeds. The result was expressed as percentage. Seed germination was tested following sand culture in Trays (Islam et al., 2013) using wet sterilized sands. Chilli Seeds were treated with different treatments and were sown in trays containing sterilized sands. Watering was done to maintain soil moisture. Trays were kept in Net-house, Seed Pathology Center (SPC), Bangladesh Agricultural University (BAU), Mymensingh, for protecting young and delicate seedling from heavy shower and scorching sunlight.

\section{Inspection of incubated seed samples and identification of fungi}

Incubated seeds were observed under stereomicroscope at 16x and 25x magnification for recording the associated fungi grown on seed surface. The associated fungi were detected by observing their growth characters on the incubated seeds on blotter paper following the keys outlined by Ramnath et al. (1970). 


\section{Vigour test}

Vigour index of chilli seedlings were examined after 14 days of sowing. Seedling vigor was determined following the formula given by Baki and Anderson (1972).

The collected data were analyzed using statistical computer package MSTAT-C. Treatment means were compared by DMRT.

\section{Results}

\section{Identification of seed borne fungi of chilli}

After 14 days of incubation of seeds on wet blotting paper, the growing fungi were observed under microscope and identified. Total five different fungi were recorded (Table 1). These fungi were Alternaria tenuis, Aspergillus spp, Colletotrichum capsici, Curvularia lunata, and Fusarium spp. Colonies of Aspergillus spp were found as powdery masses of yellow-green spores on the upper surface of the seeds. Hyphal growth occurred by thread like branching and produced mycelium. Hyphae were septate and hyaline. Conidia produced in thick mycelial mats. The conidiophore were rough and colourless. Colletotrichum capsici produced single or multiple acervuli on the ungerminated seeds and infected emerged seedlings. The acervuli were cushion like and dark brown to black in colour with pointed sita. The conidia were hyaline, sickle shaped or curved. In case of Curvularia lunata, profuse, loose, brown to black mycelial growth on seed surface was observed. Short, erect and rigid conidiophores arising from mycelia bear conidia both laterally and of the tip in clusters. Conidia were coloured, 3-4 celled and lunar shaped curved. Fusarium spp. produced loose and whitish mycelial growth along with hyaline sickle shaped, septate, 4-6 celled, hyaline macroconidia. Mycelia growth of Alternaria tenuis was found on seeds and even on the blotter surrounding of the seeds. The conidiophores of Alternaria tenuis were coloured and septated.

Table 1. Effect of different seed treatments on \% seed yielding seed borne fungi of chilli seeds collected from different locations

\begin{tabular}{|c|c|c|c|c|c|c|}
\hline Location & Treatment & $\begin{array}{c}\text { Alternaria } \\
\text { tenuis }\end{array}$ & $\begin{array}{c}\text { Aspergillus } \\
\text { spp. }\end{array}$ & $\begin{array}{c}\text { Colletotrichum } \\
\text { capsici }\end{array}$ & $\begin{array}{c}\text { Curvularia } \\
\text { lunata }\end{array}$ & $\begin{array}{c}\text { Fusarium } \\
\text { spp. }\end{array}$ \\
\hline \multirow{6}{*}{$\begin{array}{l}\text { Lakshmonkhola } \\
\text { village }\end{array}$} & $\mathrm{T}_{1}$ & $7.00 \mathrm{a}$ & $5.00 \mathrm{a}$ & $15.50 \mathrm{a}$ & $9.00 \mathrm{a}$ & $8.00 \mathrm{a}$ \\
\hline & $\mathrm{T}_{2}$ & $2.00 \mathrm{~b}$ & $3.00 \mathrm{~b}$ & $6.00 \mathrm{~b}$ & $3.00 \mathrm{~b}$ & $3.00 \mathrm{~b}$ \\
\hline & $\mathrm{T}_{3}$ & $1.00 \mathrm{~b}$ & $1.00 \mathrm{c}$ & $2.00 \mathrm{C}$ & $1.00 \mathrm{~b}$ & $1.00 \mathrm{~b}$ \\
\hline & $\mathrm{T}_{4}$ & $2.00 \mathrm{~b}$ & $3.00 \mathrm{~b}$ & $5.00 \mathrm{bc}$ & $3.00 \mathrm{~b}$ & $4.00 \mathrm{ab}$ \\
\hline & $\mathrm{T}_{5}$ & $2.00 \mathrm{~b}$ & $2.00 \mathrm{bc}$ & $5.25 \mathrm{bc}$ & $2.00 \mathrm{~b}$ & $2.00 \mathrm{~b}$ \\
\hline & Level of Signi. & $\star \star$ & ** & ** & $\star \star$ & $\star \star$ \\
\hline \multirow[t]{6}{*}{ Mugarchar village } & $\mathrm{T}_{1}$ & $5.20 \mathrm{a}$ & $5.80 \mathrm{a}$ & $16.75 \mathrm{a}$ & $5.00 \mathrm{ab}$ & $12.00 \mathrm{a}$ \\
\hline & $\mathrm{T}_{2}$ & $2.00 \mathrm{bc}$ & $2.00 \mathrm{c}$ & $2.00 \mathrm{bc}$ & $3.00 \mathrm{c}$ & $2.00 \mathrm{c}$ \\
\hline & $\mathrm{T}_{3}$ & $1.00 \mathrm{c}$ & $3.00 \mathrm{~b}$ & $1.00 \mathrm{c}$ & $4.75 \mathrm{a}$ & $4.00 \mathrm{bc}$ \\
\hline & $\mathrm{T}_{4}$ & $4.00 \mathrm{ab}$ & $2.00 \mathrm{c}$ & $3.00 \mathrm{bc}$ & $4.25 \mathrm{bc}$ & $7.00 \mathrm{ab}$ \\
\hline & $\mathrm{T}_{5}$ & $5.00 \mathrm{a}$ & $5.00 \mathrm{ab}$ & $4.00 \mathrm{~b}$ & $4.50 \mathrm{ab}$ & $3.00 \mathrm{bc}$ \\
\hline & Level of Signi. & * & * & $\star *$ & * & $\star \star$ \\
\hline \multirow[t]{6}{*}{ Tulatuli village } & $\mathrm{T}_{1}$ & $13.00 \mathrm{a}$ & $6.00 \mathrm{a}$ & $22.00 \mathrm{a}$ & $4.50 \mathrm{a}$ & $15.00 \mathrm{a}$ \\
\hline & $\mathrm{T}_{2}$ & $4.00 \mathrm{~b}$ & $3.00 \mathrm{~b}$ & $5.00 \mathrm{~b}$ & $3.00 a b$ & $2.00 \mathrm{~b}$ \\
\hline & $\mathrm{T}_{3}$ & $2.00 \mathrm{~b}$ & $1.00 \mathrm{~b}$ & $3.00 \mathrm{~b}$ & $1.50 \mathrm{~b}$ & $2.00 \mathrm{~b}$ \\
\hline & $\mathrm{T}_{4}$ & $3.00 \mathrm{~b}$ & $3.00 \mathrm{~b}$ & $4.00 \mathrm{~b}$ & $3.00 \mathrm{ab}$ & $4.00 \mathrm{~b}$ \\
\hline & $\mathrm{T}_{5}$ & $2.00 \mathrm{~b}$ & $3.00 \mathrm{~b}$ & $5.00 \mathrm{~b}$ & $4.00 \mathrm{a}$ & $2.00 \mathrm{~b}$ \\
\hline & Level of Signi. & $\star \star$ & $\star \star$ & $\star *$ & * & $\star \star$ \\
\hline
\end{tabular}

* and ${ }^{* *}$ indicates $5 \%$ and $1 \%$ level of significance, respectively. Data in column in location wise having similar letter(s) do not differ significantly. Here, $\mathrm{T}_{1}=$ Control, $\mathrm{T}_{2}=$ Garlic (1:1), $\mathrm{T}_{3}=\mathrm{BAU}$-biofungicide $(0.3 \%), \mathrm{T}_{4}=$ Bavistin (0.2\%) and $\mathrm{T}_{5}=\mathrm{Tilt} 250 \mathrm{EC}(0.2 \%)$ 


\section{Effect of different treatments on seed borne fungi}

Location wise effect of different treatments on seed borne fungi of chilli seeds collected from Lakshmonkhola Mugarchar and Tulatuli differed significantly among the different treatments (Table 1). In the seed sample of Lakshmonkhola, among the five different treatments the highest number of fungi was recorded in non-treated control seeds $\left(T_{1}\right)$. Lowest number of seed borne fungi was observed in all samples which were treated with BAU-Biofungicide $\left(T_{3}\right)$. Statistically similar number of fungi was observed in treatment $T_{2}, T 4$ and $T_{5}$. Statistically reduced number of Alternaria tenuis was observed by using BAU-Biofungicide followed by garlic extract, Bavistin (0.2\%) and Tilt 250EC (2.0\%). After BAUbiofungicides, second highest reduction of Aspergillus spp, Colletortichum capsici, Curvularia lunata and Fusarium spp, was observed in case of seeds treated with Tilt 250EC (0.2\%).

In case of seed sample from Mugarchar the highest number of fungi was recorded in non-treated control seeds $\left(T_{1}\right)$. Lowest number of Alternaria tenuis and Colletortichum capsici, was observed in BAUBiofungicide treated seeds and lowest number of Curvularia lunata and Fusarium spp was observerd in garlic $\left(T_{2}\right)$ treated seeds. In case of Aspergillus spp, reduced number was found by the both treatment of garlic extract and BAU-Biofungicide.

In the seed sample of Tulatuli the highest number of fungi was recorded in non-treated control seeds $\left(T_{1}\right)$. Lowest number of fungi was observed in BAU-Biofungicide treated seeds $\left(T_{3}\right)$. In case of Alternaria tenuis, statistically reduced number was observed by BAU-Biofungicide and Till 250EC (2.0\%). In case of Fusarium spp, reduced number was found by garlic extract, BAU-Biofungicide, Bavistin (0.2\%) and Tilt 250EC (2.0\%).

\section{Effect of different treatments on seed germination (\%) and seedling vigour of chilli seeds}

Effect of different treatments on percent seed germination and vigor index of chilli seeds collected from three villages of Megna Upazilla under Comilla District was recorded (Table 2 \& 3). Both in wet blotter and sand culture, highest germination (\%) of chilli seeds was recorded in the seeds treated with BAUBiofungicide followed by Bavistin and garlic. Lowest germination was observed in Tilt 250EC treated seed preceded by untreated control. In case of seedling vigour, highest vigour index was found in BAUbiofungicide treated seeds and lowest vigour index was observed in Tilt 250EC treated seed preceded by untreated control.

Table 2. Effect of different treatments on percent seed germination of chilli seeds collected from three villages of Megna upazilla under Comilla district

\begin{tabular}{|c|c|c|c|c|c|c|}
\hline \multirow[t]{3}{*}{ Treatment } & \multicolumn{6}{|c|}{$\%$ Germination of seeds } \\
\hline & \multicolumn{2}{|c|}{ Lakshmonkhola village } & \multicolumn{2}{|c|}{ Mugarchar village } & \multicolumn{2}{|c|}{ Tulatuli village } \\
\hline & Wet Blotter & Wet sand & Wet Blotter & Wet sand & Wet Blotter & Wet sand \\
\hline $\mathrm{T}_{1}$ & 72.5 & 64.2 & 64.75 & 59.9 & 71.75 & 67.3 \\
\hline $\mathrm{T}_{2}$ & 78.75 & 76.8 & 66.25 & 62.5 & 74.25 & 54.6 \\
\hline $\mathrm{T}_{3}$ & 89.5 & 81.1 & 71.75 & 68.0 & 82.5 & 57.8 \\
\hline $\mathrm{T}_{4}$ & 83.5 & 71.5 & 62.5 & 66.3 & 74.5 & 49.7 \\
\hline $\mathrm{T}_{5}$ & 44.75 & 38.2 & 41.0 & 35.8 & 39.5 & 33.8 \\
\hline Level of Signi & ** & k* & ** & * & & \\
\hline
\end{tabular}

** indicates $1 \%$ level of significance. Data in column having similar letter(s) do not differ significantly. Here, $\mathrm{T}_{1}=\mathrm{Control}$, $\mathrm{T}_{2}=$ Garlic (1:1), $\mathrm{T}_{3}=$ BAU-biofungicide (0.3\%), $\mathrm{T}_{4}=$ Bavistin $(0.2 \%)$ and $\mathrm{T}_{5}=$ Tilt $250 \mathrm{EC}(0.2 \%)$ 
Table 3. Effect of different treatments on Vigour index of chilli seeds collected from three villages of Megna upazilla under Comilla district

\begin{tabular}{c|cccc}
\hline \multirow{2}{*}{ Treatment } & \multicolumn{3}{|c}{ Vigour index of chilli seedlings } \\
\cline { 2 - 4 } & Lakshmonkhola village & Mugarchar village & Tulatuli village \\
\hline $\mathrm{T}_{1}$ & $374.46 \mathrm{~d}$ & $257.31 \mathrm{~d}$ & $254.59 \mathrm{~d}$ \\
$\mathrm{~T}_{2}$ & $465.44 \mathrm{~b}$ & $370.50 \mathrm{~b}$ & $310.10 \mathrm{~b}$ \\
$\mathrm{~T}_{3}$ & $494.56 \mathrm{a}$ & $403.23 \mathrm{a}$ & $333.37 \mathrm{a}$ \\
$\mathrm{T}_{4}$ & $434.19 \mathrm{C}$ & $354.30 \mathrm{C}$ & $293.82 \mathrm{c}$ \\
$\mathrm{T}_{5}$ & $50.00 \mathrm{e}$ & $62.08 \mathrm{e}$ & $47.50 \mathrm{e}$ \\
\hline Level of Signi. & $\star \star$ & $\star \star$ & $\star \star$ \\
\hline
\end{tabular}

** indicates $1 \%$ level of significance. Data in column having similar letter(s) do not differ significantly.

Here, $\mathrm{T}_{1}=$ Control, $\mathrm{T}_{2}=$ Garlic (1:1), $\mathrm{T}_{3}=\mathrm{BAU}$-biofungicide (0.3\%), $\mathrm{T}_{4}=$ Bavistin $(0.2 \%)$ and $\mathrm{T}_{5}=\mathrm{Tilt} 250 \mathrm{EC}(0.2 \%)$

\section{Discussion}

Seed-borne fungi cause considerable damage to chilli crop. In the present investigation, prevalence of seed borne fungi in three chilli seed samples of three villages under comilla district of Bangladesh and their control through biological and chemical were studied. Five species of fungi viz. Colletotrichum capsici, Alternaria tenuis, Aspergillus spp., Fusarium spp., and Curvularia lunata were detected from the collected seeds which supports the findings of Haque et al. (1997) who reported similar types of seed borne fungi in chilli. The present findings clearly showed that the detected fungi significantly reduced seed germination. The prevalence of fungal infections and seed germination varied depending on chilli varieties of seed collection. This is in agreement with the observations made by Begum and Momin (2000). Moreover, the variation of seed borne fungi with variety and location has been observed in a number of other crops viz., tomato, cucumber, white gourd, brinjal, okra and chilli by different research workers (Fakir, 2000; Begum and Momin, 2000; Alimova et al.,2002). Germination of seeds of the ten selected chilli varieties collected from five different locations of saline area varied significantly from $5.5 \%-80 \%$ that indicated germination below the national standard (90\%). The cause of low germination encountered in the present study could partly be due to improper handling and processing of seeds after harvest by the farmers. Germination failure might have also been caused due to fungal infections (Islam and Monjil, 2016b).

The percent seed-borne infection of all the identified associated fungi in chilli seeds was reduced significantly by the seed treatment with BAU-Biofungicide (3\%) followed by garlic (1:1). Sagar et al. (2005) observed that Trichoderma harzianum was effective in reducing seed borne infection of Fusarium moniliforme and increasing seedling vigour and seed germination. Fakir and Khan (1992) reported that garlic is effective as seed dresser in inhibiting the mycelia growth and spore germination of a number of fungi. Sarhan and Shibly (2003) reported that Trichoderma harzianum was superior to other bio-control agents in terms of reduction of infection of Aspergillus niger. The association of seed borne Colietotrichum capsici of chilli has also been observed by Basak et al. (1989).

The effect of different treatments on the germination of chilli seeds was significantly influenced by the treatments. The highest and lowest germination were recorded in BAU-Biofungicide (89.50\%) and Tilt 250 EC (33.8\%), respectively. Ahmed et al. (2013) reported that Garlic extract (1:1) was best for successful reduction of seed-borne infection which increased seed germination up to $68.39 \%$ over control. This result is also supported by Bhuiyan et al. (2013) and Khaleduzzaman (1996). It was found that Tilt 250EC reduced seed germination of wheat but produce healthy seedlings (Ashraf, 2015). Considering the overall dimensions of treatments and conditions, it is clear that BAU-Biofungicide (3\%) and garlic extract (1:1) showed better performance for reducing of the chilli seed borne diseases, and increasing seed health and seedling vigour. 


\section{References}

Ahmed, H.U. and Hossain, M.M. 1985. Crop Disease Survey and Establishment of a Herbarium at BARI, Plant Pathology Division,Bangladesh Agricultural Research Institute, Joydebpur, Gazipur. 107 P

Ahmed, M., Hossain, I., Hassan, K. and Dash, C.K. 2013. Efficacy of Different Plant Extract on Reducing Seed Borne Infection and Increasing Germination of Collected Rice Seed Sample. Universal J. of Plant Science 3: 66-73.

Alimova, F.K., Zakharova, N.G., Asghar, M.G., Fattahkova, A.N. and Garusov, A.V. 2002. The quarantine control and the methods of disinfection of tomato and cucumber seeds in different regions of Russian Federation. Pakistan J. Sci. and Industrial Res. 45 (3): 196.

Ashraf, T.A. 2015. Health of wheat seeds of some selected locations and management of leaf spot in the field. MS Thesis, Department of Plant Pathology, Bangladesh Agricultural University, Mymensingh.

Baki, A.A. and Anderson, J.D. 1972. Physiological and biochemical deterioration of seeds. In TT Koziowski, ed, Seed Biology, Vol II. Academic Press, New York, pp 283-315.

Basak, A.B., Mridha, M.A.U. and Fakir, G.A. 1989. Seed borne fungi associated with chilli seeds collected from Chittagong district (Bangladesh). Bangladesh Botanical society, Dhaka (Bangladesh), Chittagong Univ. (Bangladesh. Proceedings of the 6th National Botanical Conference, Chittagong). BBS. 1989, 34 p.

BBS. Bangladesh Bureau of statistics. 2016. Yearbook of Agricultural Statistics of Bangladesh-2015. Statistics and Information Division, Ministry of Planning, Government of the People's Republic of Bangladesh.

Begum, H.A. and Momin, A. 2000. Comparison between two detection techniques of seed borne pathogen in cucurbits in Bangladesh. Pakistan Journal of Scientific and Industrial Res. 43 (4): 244-248.

Bhuiyan, M.R., Rashid, M.M., Khan, M.A., Hoque, M., Nessa, B., Rafi, M.Y. and Latif, M.A. 2013. Eco-friendly Management of Seed Borne fungi for Sustainable Crop Production. Life Science Journal .10 (4): 1640-1650.

Chowdhury, S.P., Hasan, M.M., Alam, S., Chowdhury, A.N. and Alam, M.S. 2005. Effect of plant extracts on seed borne fungi of Lentil (Lens esculenta Moench). Bangladesh J. crop Sci. 16(2):197-205.

Fakir, G.A. 2000. An annotated list of seed-borne diseases in Bangladesh. Seed Pathology Laboratory. Dept. of Plant Pathol., BAU, Mymensingh.p.20.

Haque, A.H.M.M. 1997. Control of major seed borne fungi of chilli (Capsicum annum L.) M.S. Thesis Dept. of Plant Pathology, Mymensingh.

Hasan, M.M. and Alam, S. 2007. Efficacy of Trochoderma harzianum treated seeds on field emergence, seedling disease, leaf blight severity and yield of wheat cv. Gourab and Shourav under field condition. Intl. J. Bio-Res. 3(6):23-30.

Islam, M.M. and Monjil, M.S. 2016a. Effect of aqueous extracts of some indigenous medicinal plants on sheath blight of rice. J. Bangladesh Agril. Univ. 14(1):7-12.

Islam, M.S. and Monjil, M.S. 2016b. Effect of seed washing either alone or in combination with garlic extract and Knowin 50WP on quality of jute seeds. Asian Journal of Medical and Biological Research, 2(2): 318-323.

Islam M.S., Uzzal M.S.I., Mallik, K. and Monjil, M.S. 2013. Management of seed mycoflora on mesta (Hibiscus sabdariffa) by seed washing, garlic extract and Knowin. Progress. Agric. 24 (1\&2): 1-7.

ISTA (International Seed Testing Association). 2001. International Rules for Seed Testing. Rules Amendments. Seed Sci. and Tech. 29 (2): 1-127.

Khaleduzzaman, M. 1996. Control of seed borne prevalence by seed treatment in wheat (Triticum aestivum). M.S. Thesis. Dept. of Plant Pathology, Bangladesh Agricultural University, Mymensingh, Bangladesh. pp. 1-82.

Monjil, M.S., Nozawa, T., Shibata, Y., Takemoto, D., Ojika, M. and Kawakita, K. 2015. Methanol extract of mycelia from Phytophthora infestans-induced resistance in potato. Comptes Rendus Biologies. C. R. Biologies. 338: 185-196.

Ramnath, Neergaard, P. and Mathur, S.B. 1970. Identification of Fusarium of chilli seeds. Seed Res. 6(1): 23-30.

Sagar, S.D., Hegde, Y.R., Kulkarni, S., and Rao, M.S.L. 2005. Biocontrol of seed mycoflora of rice. Annals of Biology. 21: $217-220$.

Sarhan, A.R.T. and Shibly, M.K.A. 2003. Biological control of pathogenic fungi associated with rice seeds. Arab J. Plant Protection 21: 102-108.

Shoulkamy, M.A., Guebitz, G.M., EL-Katatny, M.H.A., Shaban, G.M. and Abdel Zaher, H.M.A. 2006. Antagonism of Trochoderma or Gliocladium species on two phytopathogenic species of Fusarium. J. Natural fibers. 3(2\&3):1-17. 